\title{
Physical characterization of the fruit and nutritional value and microbiology quality of the Pentadesma butyracea fruit pulp collected from various parks in Benin
}

\section{Bernolde Paul Ayegnon ( $\nabla$ ayegnonberni@gmail.com )}

Laboratoire de Valorisation et de Gestion de la Qualité des Bio ingrédients Alimentaires (LABIO), Université d'Abomey-Calavi

\section{Ifagbémi Bienvenue Chabi}

Laboratoire de Valorisation et de Gestion de la Qualité des Bio ingrédients Alimentaires (LABIO), Université d'Abomey-Calavi

\section{Folachodé Ulrich Gildas Akogou}

Université de Parakou

\section{Adéchola Pierre Polycarpe Kayodé}

Laboratoire de Valorisation et de Gestion de la Qualité des Bio ingrédients Alimentaires (LABIO), Université d'Abomey-Calavi

\section{Research Article}

Keywords: P. butyracea, Nutritionnal composition, microbiology quality, antioxidant activity

Posted Date: March 26th, 2021

DOI: https://doi.org/10.21203/rs.3.rs-296463/v1

License: (c) (i) This work is licensed under a Creative Commons Attribution 4.0 International License. Read Full License 
Physical characterization of the fruit and nutritional value and microbiology quality of the Pentadesma butyracea fruit pulp collected from various parks in Benin

Bernolde Paul Ayegnon ${ }^{1 *}$, Ifagbémi Bienvenue Chabi ${ }^{1}$, Folachodé Ulrich Gildas Akogou ${ }^{1,2}$ \& Adéchola Pierre Polycarpe Kayodé ${ }^{1}$

${ }^{1}$ Laboratoire de Valorisation et de Gestion de la Qualité des Bio ingrédients Alimentaires (LABIO) ; Faculté des Sciences Agronomiques ; Université d'Abomey-Calavi; 03 BP 2819 Jericho Cotonou, Bénin.

${ }^{2}$ Département de Nutrition et Sciences Agro-Alimentaires (NSAA), Faculté d'Agronomie, Université de Parakou, Bénin.

* Corresponding author: Tel: (+229) 97199536; E-mail address: ayegnonberni@ gmail.com 


\begin{abstract}
In Benin, Pentadesma butyracea fruit pulp undergoes significant post-harvest loss due to its low valorization. The collected fruits in five parklands from a survey of transformer's perception were characterized through their visual observations, the determination of their dimensions and pulp proportions. The nutritional value of pulp was evaluated through its chemical characterization. The results of this study revealed that four shapes (ellipsoid, globular, ovoid, ellipsoid twisted) identify the physical aspect of $P$. butyracea fruits in the $P$. butyracea parklands. The average length, diameter at the equator, mass and pulp proportion of fruits were $130.93 \mathrm{~mm}, 86.98 \mathrm{~mm}, 125.63 \mathrm{~g}$ and $35.79 \%$, respectively. The physicochemical characterization showed that the P. butyracea fruit pulp contained 3.37-3.41 pH, 3.33-4.61\% protein, 20.37 - 20.78\% fiber, 2.78-3.57\% ash, 6.31-6.51\% crude lipid, 85.77-86.47\% moisture, 21.54-23.22 $\mathrm{mg} / \mathrm{ml}$ total phenolics, $0.73-1.03 \%$ acidity titratable, $65.10-66.94 \%$ carbohydrates, 335.75-338.99 kcal calorie and minerals (Ca, Fe, Zn, Mn). The antioxidant activity result showed that the $P$. butyracea fruit pulp is a valuable source of antioxidant pigments. Faecal coliforms are not detected in pulps and the aerobic mesophilic bacteria, yeasts and moulds, and Staphylococcus aureus were below detection level in P. butyracea fruit pulps.
\end{abstract}

Key words: $P$. butyracea, Nutritionnal composition, microbiology quality, antioxidant activity

\title{
Introduction
}

P. butyracea Sabine (Clusiaceae) is a ligneous forest species with multipurpose uses. It is widely distributed in Africa fromGuinea-Bissau to thewest of the Democratic Republic of Congo $^{1}$. P. butyracea is found in the centre and northern part of Benin in forest galleries and along waterways ${ }^{2,3}$. The $P$. butyracea tree gives a fruit, made up of pulp and seeds. The seeds are the element of the fruit more nowadays exploited because it contains an almond rich in butter. The rural population used P. butyracea butter in cosmetic and in the manufacturing of soap ${ }^{4}$. This butter is mostly used for food preparation, cosmetic and therapeutic applications because of its yellow colour, hard texture, relatively sweet taste, softening, lubricating and healing qualities ${ }^{5}$. Comparative studies carried out by ${ }^{5}$ on P. butyracea and shea butters, showed that $P$. butyracea butter is clearly better than shea butter mostly on the organoleptic level. ${ }^{6}$ evaluated the physicochemical characteristics of $P$. butyracea butter and reported that the oil content was $419.0 \mathrm{~g} \mathrm{~kg}-1$, crude protein content was $44.0 \mathrm{~g} \mathrm{~kg}-1$, lysine content was $3.2 \mathrm{~g}$ $\mathrm{kg}-1$ dry matter, methionine content was $1.6 \mathrm{~g} \mathrm{~kg}-1$ and cysteine was $1.5 \mathrm{~g} \mathrm{~kg}-1$. 
In spite of the strong knowledge of the biochemical composition of the P. butyracea kernels and potential application of its butter in food, in cosmeic and therapeutic field, there is no information on the physicochemical and biactive properties, microbiological and sensorial characteristics of $P$. butyracea fruit pulp. During $P$. butyracea butter extraction, the fruit pulp undergoes significant loss because of the ignorance of the nutritional value and bioactive properties of this part of the fruit. This pulp is almost unutilised, unexploited for several reasons. One of the reasons is the ignorance by the populations of the nutritional value of pulp. More than $99 \%$ of this pulp are thrown by the gatherers in spite of its potentialities. Studies carried out on the pulp of the shea fruit from $\mathrm{Chad}^{7}$, Nigeria ${ }^{8}$ and $\mathrm{Uganda}^{9}$, showed that it contains a significant quantity of nutritive elements such as the glucides, the proteins, the fibres, minerals and the vitamins. It is then necessary to develop technologies of valorization of $P$. butyracea fruit pulp in Benin. For this reason, it is important to study the nutritional quality of the fruits pulp in Benin. The present study evaluated the nutritional value and microbiology quality of the Pentadesma butyracea fruit pulp collected from various parks in Benin and determined the various uses of fruit pulp using a quantitative survey approach and the Physical characterization of the fruit.

\section{Materials and methods}

\section{Survey and data collection}

The study was undertaken in five municipalities of nord Benin, namely Bassila, Tchaourou, Toucountouna, Natitingou and Kandi. An investigation was conducted between May and June 2020 in villages having a tradition of $P$. butyracea fruits processing. All participans were more than 18 years, selected from the study sites. The study interest and procedure were explained to the community through village leaders. Therefore, all subjects approved the activity because they understood that it will allow them to valorize the $P$. butyracea fruit pulp. Each participant provided informed consent prior to responding to the survey. Individuals who did not provide informed consent could not proceed with the survey. This survey was approved by the Institution Ethics Board and the School of Nutrition and Food Sciences and Technologies (SNFST) of Abomey-Calavi University (UAC), approval $\mathrm{N}^{\circ}$ F-025-2020-SNFST. To determine adequate number of respondents for our survey among the $P$. butyracea actors per parkland, the following formula was used: $\mathrm{Ni}=4 \mathrm{Pi}(1-\mathrm{Pi}) / \mathrm{d} 2$ where $\mathrm{Ni}$ is the total number of $P$. butyracea actors to be surveyed in parkland $\mathrm{i}, \mathrm{Pi}$ is the proportion of $P$. butyracea actors found in previous studies in parkland $\mathrm{i}$, and $\mathrm{d}$ is the expected error margin in the conclusion, which was fixed at $0.1^{10}$. Based on this method, a total of 260 subjects distributed in twelve 
villages of aforementionned municipalities was obtained. Data were collected by administering questionnaires to randomly selected and willing respondents. The questionnaires included the following aspects: $P$. butyracea actor's perception on fruit pulp, various uses, collection state and various methods of collection of the fruits of $P$. butyrace. In addition, the various fruit shapes available in each commune was determined.

\section{Subjects}

The socio-demographic characteristics of the participants in the quantitative survey were as follows. Subjects were 180 females and 80 males. They were processors of $P$. butyracea butter. Their socio-cultural origin was diverse. Most of them were Nago (20\%), Ditamari (19.23\%), Anii (15.38\%), Kotocoli (11.54\%), Waama (14.23\%), Boo (13.46\%) and Fulani (6.15\%). Sixtyfive percent of the respondents were 35-50 years old, $29.45 \%$ between 20 and 34 and 5.87\% over 51. Their educational background was poor, as $79.5 \%$ of them were illiterate and only $20.5 \%$ had attended primary school. This reflects the general education level in the country. They practise different religions, i.e. practitioners of endogenous religions (7.7\%), Muslims (30.2\%) and Christians (62.1\%).

\section{Samples collection}

The fruits of $P$. butyracea were collected from May to June 2020 in the forests galleries of four communities in northern Benin that is Tchaourou $\left(8^{\circ} 45^{\prime}-9^{\circ} 20^{\prime} \mathrm{N}\right.$ and $\left.2^{\circ} 10^{\prime}-3^{\circ} 40^{\prime} \mathrm{E}\right)$, Kandi $\left(11^{\circ}\right.$ $7^{\prime}-11^{\circ} 43^{\prime} \mathrm{N}$ and $\left.2^{\circ} 56^{\prime}-2^{\circ} 13^{\prime} \mathrm{E}\right)$, Toucountouna $\left(10^{\circ} 20^{\prime}-10^{\circ} 45^{\prime} \mathrm{N}\right.$ and $\left.1^{\circ} 10^{\prime}-1^{\circ} 40^{\prime} \mathrm{E}\right)$ and Bassila $\left(8^{\circ} 30^{\prime}-9^{\circ} 30^{\prime} \mathrm{N}\right.$ and $\left.1^{\circ} 00^{\prime}-2^{\circ} 30^{\prime} \mathrm{E}\right)$. In each location ripe fallen fruits were collected from 30 trees packed in jute bags and transported to the laboratory. The fruits from each site were then bulked together. The fruits were depulped and fruit pulp were mixed for different chemicals analyses.

\section{Physical charecterization of the $P$. butyracea fruits}

The fruits evaluation has been done immediately after the sample collection. The characteristics analysed were: diameter, length, fruit mass and fruit pulp mass. Diameter and length $(\mathrm{mm})$ of the fruits were measured with a precision caliper $(0.01 \mathrm{~mm})$ and mass of the fruits $(\mathrm{fm})$ and pulps mass (pm) were determined using balance with precison is 1/10.000. Measurements were performed on 50 fruits chosen at random per sample and by shape (ellipsoid, globular, ovoid and ellipsoid twisted) from each park. The generated values allow calculating the proportion of pulp $(\%)=\mathrm{pm} / \mathrm{fm} \times 100$. 


\section{Evaluation of physicochemical composition of $P$. butyracea fruit pulp}

The proximate analysis of fruit pulp samples were analyzed using standard methods ${ }^{11}$. The moisture content was determined by drying about five grams of the fresh sample in an oven at $105^{\circ} \mathrm{C}$ to constant weight. Crude ash was determined by incineration of $5 \mathrm{~g}$ of sample in a muffle furnace at $550^{\circ} \mathrm{C}$ for $8 \mathrm{~h}$. The nitrogen $(\mathrm{N})$ content was estimated by micro-Kjeldahl method and crude protein content calculated as N\% x6.25. Crude lipid was exhaustively Soxhlet extracted from $5 \mathrm{~g}$ sample with nhexane for 4 hours. Crude fibre content was determined by treating $2 \mathrm{~g}$ sample with $1.25 \%(\mathrm{~W} / \mathrm{V}) \mathrm{H} 2 \mathrm{SO} 4$ and $1.25 \%(\mathrm{~W} / \mathrm{V}) \mathrm{NaOH}$. Minerals (calcium, magnesium, iron and zinc) of the samples were then analyzed with Atomic Absorption Spectrophotometer model AAnalysit- 400. The $\mathrm{pH}$ was determined using a digital pHmeter (HI8418 ; Hanna instruments, Limena, Italy) calibrated with buffers at pH 4.0 and 7.0 (WTW, Weilheim, Germany). The titratable acidity, expressed as lactic acid, was carried out using the method described by ${ }^{12}$. The Brix values were carried out using a refractometer. The available carbohydrate $(\mathrm{CHO})$ was calculated by difference. Calorific value $(\mathrm{CV})$ was determined using the following equation:

$\mathrm{CV}(\mathrm{kcal} / 100 \mathrm{~g})=(\mathrm{CHO} \times 4)+(\mathrm{CL} \times 9)+(\mathrm{CP} \times 4)$ with $\mathrm{CL}=$ Lipides, $\mathrm{CP}=$ Proteines

\section{Microbiological characteristics of $P$. butyracea fruit pulp}

Measurements were performed on 10 fruits chosen at random per sample. Fruit pulps samples were analyzed for total bacterial count, total coliforms, thermotolerant coliforms, yeasts and moulds and Staphylococcus aureus according to standard methods of ${ }^{13}$. Briefly, $10 \mathrm{~g}$ of fruit pulps were weighed into sterile bags and homogenized in $90 \mathrm{ml}$ of sterile peptone water $(0.1 \%)$ and $\mathrm{NaCl}(0.85 \%)$. Serial dilutions were made in BPW. Aerobic mesophilic bacteria were analysed using plate count agar after incubation at $30^{\circ} \mathrm{C}$ for $72 \mathrm{~h}$, total coliforms were enumerated on violet red bile agar after incubation at $30^{\circ} \mathrm{C}$ for $24 \mathrm{~h}$ ), thermotolerant coliforms on Violet Red Bile Agar at $44^{\circ} \mathrm{C}$ for $24 \mathrm{~h}$, yeasts and moulds on malt extract agar at $25^{\circ} \mathrm{C}$ for 72 h. S. aureus determined on Baired Parker agar supplemented with egg yolk and the plates incubated at $37^{\circ} \mathrm{C}$ for $48 \mathrm{~h}$.

\section{Preparation of extracts for the determination of total phenolics and antioxidant activity}

Samples were extracted in methanol/HCl (99:1 (v/v) following the method described by ${ }^{14}$. Fifty milligrammes $(50 \mathrm{mg})$ of each sample were extracted at room temperature with $1.5 \mathrm{~mL}$ of solvent under agitation using a magnetic stirrer for $30 \mathrm{~min}$. The mixtures were centrifuged at 
$2500 \mathrm{~g}$ for $10 \mathrm{~min}$ and the supernatants were collected. The residues were re-extracted twice under the same conditions, resulting in $3 \mathrm{~mL}$ crude extract. All extracts were used as they were after centrifugation for various analyses.

\section{Total phenolics determination}

Total phenolics were measured following the method of ${ }^{15}$ modified by ${ }^{14}$ as follows: to $300 \mu \mathrm{L}$ of extract, $4.2 \mathrm{~mL}$ of distilled water, $0.75 \mathrm{~mL}$ of Folin-Ciocalteu's reagent (Merck, Germany) and $0.75 \mathrm{~mL}$ of sodium carbonate solution (200 g L-1) were added. After incubation for $30 \mathrm{~min}$, the optical density was measured at $760 \mathrm{~nm}$ against a blank. Gallic acid was used as standard and the results were expressed as gallic acid equivalent (GAE) per g of sample DM.

\section{Antioxidant Activity determination}

The antioxidant activity was measured using DPPH (2,2-diphenyl-1-picrylhydrazyl). The DPPH method was conducted by adaptation as described by Scherer and Godoy ${ }^{16}$. Equal volumes $(100 \mu \mathrm{L})$ of DPPH $(50 \mu \mathrm{M})$ and plant extracts $\left(12,5 \mathrm{mg} \cdot \mathrm{ml}^{-1}\right)$ were mixed and incubated for 20-30 min in the dark at room temperature. Then, the absorbance was read at $517 \mathrm{~nm}$ and the blank was a mixture of methanol and DPPH (v : v). This activity was given as \% DPPH scavenging and calculated using equation 1 :

$$
\% \text { Inhibition } \mathrm{DPPH}^{\cdot}=\frac{A_{\text {control }}-A_{\text {sample }}}{A_{\text {control }}} \times 100
$$

where $\mathrm{A}_{\text {control }}$ is absorption of DPPH solution, and $\mathrm{A}_{\text {sample }}$ is absorbance of the test sample. The half maximal effective concentration $\left(\mathrm{EC}_{50}\right)$ is the amount of sample necessary to decrease the absorbance of DPPH by 50\%. It was determined graphically using a calibration curve in the linear range by plotting the extract concentration and the corresponding scavenging effect. Ascorbic and gallic acids were used as positive controls. All the analyses were carried out in triplicate.

\section{Statistical analysis}


All data were expressed as mean \pm standard deviation $(n=3$ replicates). Data were analyzed using one-way ANOVA using SPSS 16.0. Duncan's multiple-range test was used to determine the difference between means. A significant difference was considered at the level of $\mathrm{p} \leq 0.05$.

\section{Results and discussion}

\section{Intercultural convergence uses of $P$. butyracea fruit pulp in Benin}

The different uses of $P$. butyracea fruit pulp by rural households in the study zones are presented in Table 1. Among the different ethnic groups involved in the P. butyracea fruit pulp use, the Fulani reported to know about trees producing fruits with bitter pulp and their yellow color. The fruit pulp sometimes is consumed by the farmers in the fields. P. butyracea fruit pulp is used mainly in the therapeutic applications and to a lesser extent in cosmetic and food sector. All the socio-cultural groups interviewed use the pulp for therapeutic applications. More specifically, P. butyracea fruit pulp is used by Anii (100\% of respondents), Kotocoli (96.80\% of respondents), Boo (97.30\% of respondents) and Waama socio-cultural groups $(94.30 \%$ of respondents) in the treatment of digestive system disorders such as bloated stomach and constipation. ${ }^{2}$ reported that the fruits are used to treat the digestives disorders, the genitourinary infections and also in the human consumption. Apart from this traditional utilization, $P$. butyracea pulp is also used in locally produced soap and cosmetics. For instance, the Kotocoli (89.50\% of respondents), Waama (77.6\% of respondents) and Otamari groups (67.8\% of respondents) used it in chiropodist and local soap preparation. Moreover, all socio-cultural groups interviewed use pulp to wash their pans, they also use it against rust. According the $P$. butyracea butter producers, the fruit is available from May to june. The period of abundance is the end of May in most of the parks. It are available at the beginning of the rainy season, a period characterized by general food scarcity in Sub-Saharan regions. Gathering of $P$. butyracea fruits is generally done by women and children early in the morning. They collect under the trees all fruits found without sorting. After gathering, the fruits are depulped in the field and kernels brought back home.

\section{Physical characteristics of $P$. butyracea fruits}

The dimensions of $P$. butyracea fruits from various parks in northern of Benin were presented in the Figure 1. The length of the fruits ranged from 127.31 to $136.16 \mathrm{~mm}$, with an average value of $130.93 \mathrm{~mm}$. Also, the diameter of the fruits ranged from 80.42 to $95.03 \mathrm{~mm}$, with an average value of $86.98 \mathrm{~mm}$. There was a significant difference between parks for these parameters $(\mathrm{p} \leq 0.001)$. Thus, the lowest lengtth and diameter of fruits were recorded in the 
fruits collected in Kandi, Toucountouna and Natitingou, while the fruits with the highest values were originated from Bassila and Tchaourou. Clearly, there is a big variation within the fruits of $P$. butyracea in terms of their morphological characteristics. The major factors that could affect these characteristics are the plant age, its genotype and its growing environment. The dimensions of different shapes of $P$. butyracea fruits from various parks in northern of Benin were presented in the Figure 2. The dimensions (length and diameter) of $P$. butyracea fruits varies significantly $(\mathrm{p} \leq 0.001)$ between shapes and the length of $P$. butyracea fruits shapes ranged from 108.39 to $141.48 \mathrm{~mm}$, with a mean value of $128.01 \mathrm{~mm}$. In addition, the diameter of fruits shapes ranged from 81.45 to $108.06 \mathrm{~mm}$, with an average value of $95.41 \mathrm{~mm}$. The highest lengtth and diameter of fruits were recorded to the ellipsoid, ovoid and globular shapes respectively, while the lowest lengtth and diameter of fruits were found in the ellipsoid twisted shape. In addition, more than $70 \%$ of the fruits collected in the various parks are ovoid or globular forms.

The mass of fruit, mass and proportion of pulp from various parks are presented in Table 2 . The mass of fruit from different parks ranged from 343.27 to $475.35 \mathrm{~g}$, with a mean value of 403.30 g. In the same way, the mass and proportion of pulp ranged from 95.98 to $162.50 \mathrm{~g}$, with an average value of $125.63 \mathrm{~g}$, and 32.76 to $39.12 \%$, with a mean value of $35.79 \%$, respectively. There was a significant difference between the parks studied for fruits mass, pulp proportion and pulp mass $(p<0.001)$. Thus, the highest fruit mass, pulp proportion and pulp mass were found on the fruits collected in Bassila and Tchaourou parks, while the lowest values of these parameters were observed on the fruits from Kandi and Toucountouna parks. The major factors that could affect these characteristics of fruits are rainfall. Thus, Tchaourou and Bassila are localised in the Sudano-Guinean transitional climatic zone with an average rainfall varying from 850 to $1850 \mathrm{~mm}$ and 1000 to 1300 , respectively. Kandi and Toucountouna are located in the Sudanian climatic zones with an average rainfall of 1200 and $1000 \mathrm{~mm}$, respectively ${ }^{5,17}$. Moreover, fruit mass, pulp proportion and pulp mass varies significantly $(p<0.001)$ between fruits shapes (table 3) and ranged from 241.50 to $535.25 \mathrm{~g}, 81.75$ to $204.50 \mathrm{~g}$ and 30.44 to $36.74 \%$, respectively. The highest fruit mass, pulp proportion and pulp mass of fruits were recorded to the ellipsoid, ovoid and globular shapes respectively, while the lowest values were found in the ellipsoid twisted shape. The pulp proportion obtained was lower compared to the range of $57-70 \%$ for shea fruit pulp collected from various parks in Benin ${ }^{18}$. The ovoid shape holds the most proportion of pulp (36.74\%) which is definitely higher than those of the ellipsoid twisted (33.30\%), ellipsoid (33.05\%) and globular shape (30.44\%). 


\section{Nutritional compositions of $P$. butyracea fruit pulp}

The data on the chemical composition of the P. butyracea fruit pulp, as determined, are presented in Table 4. The moisture content of the P. butyracea fruit pulp ranged from 85.77 to $86.47 \%$, with no significant different between the P. butyracea parks ( $>0.05)$. These values were similar to those of the pineapple (87\%) and apple $(86 \%)^{19}$ and shea fruit pulp from various zones in Benin $(77.56-80.89)$ reported by ${ }^{18}$. The $P$. butyracea fruit pulp would not be microbiologically stable at this moisture content as it would allow the proliferation of microorganisms. The ash content of the pulps was comparable to that of the bush mango fruitt pulp $(02.10 \%)^{20}$ but higher than the $0.33-0.71 \%$ reported for shea fruit pulp jam ${ }^{21}$. This is indicative of the high mineral content of $P$. butyracea fruit pulp. The $\mathrm{pH}$ of the pulps ranged from 3.27 to 3.41. The $\mathrm{pH}$ of the different pulps is not significantly different ( $\mathrm{p}>0.05)$. The low $\mathrm{pH}$ of the $P$. butyracea fruit pulp would not create favorable conditions for many organisms to sporulate and multiply ${ }^{20}$. The low $\mathrm{pH}$ and high acidity for these products was due to the organic acids in the fruit pulp ${ }^{22}$. These properties would confer long shelf life on the products by hindering proliferation of undesirable microorganisms ${ }^{23}$. The titratable acidity of the $P$. butyracea fruit pulp from different park in Benin ranged from 0.73 to $1.03 \%$, with significant different between the parks. The highest value of titratable acidity was found in the samples from Kandi park while the lowest values of this parameter was observed in the samples from Bassila park. The value for the titratable acidity was similar to that reported by ${ }^{19}$ in orange/pineapple juice blends $(0.47-1.27 \%)$, but higher than $0.233-0.330 \%$ obtained by ${ }^{21}$ in shea fruit pulp juice. The acids present in food not only improve its palatability but also influence its nutritive value ${ }^{20}$. The proteins value of fruit pulp from different parks ranged from 3.33 to $4.61 \% \mathrm{dw}$. There was a significant difference $(\mathrm{P} \leq 0.05)$ between the parks studied for this parameter. These proteins values were lower than that of the shea fruit pulp $(3.96-6.34 \%)$ reported by ${ }^{18}$, but is higher than $1.5-3.5 \%$ obtained by ${ }^{9}$ in Uganda and $1.09 \%$ reported by ${ }^{24}$ from the fresh shea pulp. In addition, Protein content of $P$. butyracea fruit pulp was similar to that found in mango pulp (4.8\%) reported $b y^{20}$. The differences in the protein contents may be due to environmental differences in areas of production. The crude fiber contents of the pulp ranged from 5.78 to $6.51 \%$. The values obtained for the crude fiber content of the pulp from the five different localities was very close, with no statistically significant difference $(p>0.05)$. The value of crude fibre content for $P$. butyracea fruit pulp of $20.78-20.51 \%$ is within the crude fibre values of most wild and domesticated fruits and higher than in legumes with mean values ranging between $5-6 \%{ }^{25}$. In addition, these values are high compared to the fiber value for bush 
mango pulp of $2.5 \%$ reported by ${ }^{20}$, and high than the shea fruit pulp collected from various parks in Benin with values ranging between $5.97-6.52 \%$ as reported by ${ }^{18}$. The highest crude fiber content of the $P$. butyracea fruit pulp makes it digestible beverage for children ${ }^{26}$. As crude fibre helps in the maintenance of normal peristaltic movement of the intestinal tract, diets containing high fibre content could reduce occurrence of such disorders as constipation, colon diseases, diabetes, cardiovascular diseases and obesity ${ }^{27}$. This study, thus, has indicated that $P$. butyracea fruit pulp is a rich source of energy and capable of supplying the daily energy requirements of the body. It also implies that promoting consumption of $P$. butyracea fruit pulp is of great benefit to the human diet. The values for crude lipid in this study are high compared to the crude oil value for shea fruit pulp from different shea zones in Uganda of $1.5-3.5 \%$ reported by ${ }^{9}$, and $1.4 \%$ obtained by ${ }^{20}$ in bush mango fruit pulp. The values for carbohydrates ranged from 65.10 to $66.94 \%$ and showed no significant difference ( $p>0.05)$ between the samples. This is in close relationship with the range $80.8 \%$ reported by ${ }^{20}$ for bush mango fruit pulp. The carbohydrate value was higher when compared with values $7.3-9.9 \mathrm{~g} / 100 \mathrm{~g}$ obtained by $^{28}$ in Butyrospermum paradoxum fruit pulp and $12.6-19.4 \mathrm{~g} / 100 \mathrm{~g}$ reported by ${ }^{9}$ for shea fruit pulp in different shea districts of Uganda. The pulp was rich in carbohydrate when compared with other nutrients of the fresh pulp. The energy content of the pulp varies from 335.75 to $338.99 \mathrm{kcal}$, and shows no significant different $(\mathrm{p}>0.05)$ between sites. The high fat and carbohydrate contents of the $P$. butyracea pulp contributed to the higher energy content of the pulp. The energy obtained from $P$. butyracea pulp was higher than that of $1289.2 \mathrm{kj} / 100 \mathrm{~g}$ provided by the jams processed from shea fruit pulp reported by ${ }^{21}$.

The minerals profile of the P. butyracea fruit pulp result was presented in Table 4 . The most predominant mineral found in the $P$. butyracea fruit pulp was calcium with values ranged from 1793.71 to $1921.75 \mu \mathrm{g} / \mathrm{g}$. The highest value of calcium was found in the samples from Toucountouna park while the lowest values of this mineral was observed in the samples from Tchaourou park. The calcium content was higher when compared with that of shea fruit pulp in Uganda $(37.20-95.60 \mathrm{mg} / 100 \mathrm{ml})$ reported by ${ }^{9}$ and mango fruit pulp $(190 \mathrm{mg} / 100 \mathrm{ml})^{20}$. In addition, iron and manganese were also high with values ranged from 176.44 to $205.53 \mu \mathrm{g} / \mathrm{g}$ and 40.71 to $50.31 \mu \mathrm{g} / \mathrm{g}$ respectively. Iron and manganese were highest in the samples from Toucountouna park and the lowest in the samples from Bassila and Tchaourou parks, respectively. The iron content was higher than $2.5 \mathrm{mg} / 100 \mathrm{~g}$ obtained by ${ }^{20}$ in mango fruit pulp and $27.65 \mu \mathrm{g} / \mathrm{kg}$ reported by ${ }^{24}$ from fresh shea fruit pulp in Ghana. Manganese content found 
in $P$. butyracea fruit pulp was higher than $12.50 \mu \mathrm{g} / \mathrm{kg}$ obtained $b^{24}$ from fresh shea fruit pulp in Ghana.

\section{Microbial characteristics of $\boldsymbol{P}$. butyracea fruit pulp}

Hygiene quality of $P$. butyracea fruit pulps samples from various parks in Benin was presented in Table 5. Samples of P. butyracea fruit pulp had various microbial load with low count of aerobic mesophilic germs ( 1.70 to $2.75 \log 10 \mathrm{CFU} / \mathrm{g}$ ), yeasts and moulds (1.85 to $2.97 \log 10$ CFU/g), total coliforms (1.11 to $2.37 \log 10 \mathrm{CFU} / \mathrm{g}$ ) and staphylococcus aureus (1.05 to 1.37 $\log 10 \mathrm{CFU} / \mathrm{g}$ ) (Table 1). The number of aerobic mesophilic bacteria in all collected samples was close to the international standard of $4 \log 10 \mathrm{CFU} / \mathrm{g}^{29}, 30$. However, the highest microbial count was found in sample collected in Tchaourou and Kandi parks, while the lowest microbial count was observed in fruit pulp from Bassila, Naitingou and Toucountouna. Differences between parks for the number of yeasts and moulds $(p<0.001)$ and total coliforms $(p<0.001)$ were observed, with samples collected from the Tchaourou park giving significantly higher values of yeasts and moulds compared with the samples from other parks. Water and environment may play a major role in the yeasts and moulds contamination of $P$. butyracea fruit pulp especially during washing of fruits. The highest count of yeasts and moulds is also due to the acidic nature of $P$. butyracea fruit pulps which probably favours the growth of yeasts. Moreover, no faecal coliforms were detected in all fruit pulps. Furthermore, there is no significant difference in staphylococcus aureus counts between the fruit pulp collected in various parks ( $>0.05$ ). The presence of Staphylococcus aureus in the fruit pulp is attributed to its wide spread in the environment. The primary habitat of these organisms are the interior body and skin of man and animal from where this microbes are transferred to the fruits and subsequent transfer to the fruit pulp during treatment. However, the level of all microbial enumerated in $P$. butyracea fruit pulps was under the detection limit. The acidity of pulps could be a factor that limited the development of spoilage and pathogen microorganisms in pulps.

\section{Total phenolic content and the antioxidant activities of $P$. butyracea fruit pulp}

Total phenolic content (TPC) of $P$. butyracea fruit pulp was expressed as gallic acid equivalent (GAE) per g of DM. The total phenolic content (TPC) and antioxidant activities (AA) of the pulps are shown in Table 6. The TPC values ranged between 21.54 and $25.98 \mathrm{mg} / \mathrm{ml}$ for all the fruit pulp samples. The TPC was highest $(25.98 \mathrm{mg} / \mathrm{ml})$ in fruit pulp collected in Kandi, while the lowest TPC $(21.54 \mathrm{mg} / \mathrm{ml})$ was recorded in fruit pulp sample from Toucountouna. The significant different $(\mathrm{P}<0.05)$ of TPC of the fruit pulp between parks may be explained by 
various maturity stages of the $P$. butyracea fruit. The variations of $P$. butyracea fruit TPC from various agroecologics zones could be attributed to climate and environnement factors namely rainfall and soil composition. The TPC of $P$. butyracea fruit pulp was higher than that found in honey by ${ }^{31}$, which varies from 0.23 to $0.73 \mathrm{mg}$ GAE/g. While, The TPC of $P$. butyracea fruit pulp was lower compared to propolis values $\left(22.80-77.50 \mathrm{mg}\right.$ GAE/g reported by ${ }^{32}$. In addition, the TPC of P. butyracea fruit pulp obtained in this study was higher than 226.25 $\mathrm{mg} / 100 \mathrm{~g}$ reported by ${ }^{24}$ from fresh shea fruit pulp in Ghana.

The antioxidant capacity of fruits and vegetables is an important indicator of health promoters, and many methods have been developed to evaluate this particular capacity ${ }^{33}$. In this study the anti-radical properties of the fruit pulps was performed by DPPH radical scavenging assay. $\mathrm{EC}_{50}$, the effective concentration of the extracts (mg antioxidant / $\mathrm{mg} \mathrm{DPPH}$ ) required to scavenge $50 \%$ of DPPH radical are presented. Significant difference in $\mathrm{EC}_{50}$ between the fruit pulp samples was observed $(p \leq 0.001)$. The pulp sample collected in Toucountouna park showed the highest $\mathrm{EC}_{50}$ value, whereas the pulp sample from Kandi was found to have the lowest $\mathrm{EC}_{50}$ value. A lower value would reflect greater antioxidant activity of sample. Moreover, the remaining DPPH in the fruit pulps ranged from 10.83 to $22.54 \%$. This result suggests that $P$. butyracea fruit pulp plays an important role in the scavenging of free radical.

\section{Conclusion}

This study showed that $P$. butyracea fruit pulp has high total phenolic content. In addition, $P$. butyracea fruit pulp is a valuable source of antioxidant pigments. The proximate and the mineral composition values obtained showed that $P$. butyracea fruit pulp is rich in total carbohydrates, crude fiber, calcium and iron. This fruit pulp is a good source of the minerals which are useful for the proper functioning of the body and important in the diet. Thus, consumption of $P$. butyracea fruit pulp is highly recommended in Benin.

\section{Acknowledgements}

This work was supported by The World Academy of Sciences (TWAS) and the Swedish International Development Cooperation Agency (SIDA) for financial this research study.

\section{Authors' contributions}

B.P.A. designed experiments, collected and analyzed data, and co-prepared the first draft of the manuscript. I.B.C. collected and analyzed data. F.U.G.A. collected and analyzed data. A.P.P.K. read and edited the manuscript. All authors read and approved the final manuscript. 


\section{Availability of data and materials}

All the data supporting the results are included within the article.

\section{Competing interests}

Authors declare that they have no competing interests.

\section{Additional information}

Correspondence and requests for materials should be addressed to B.P.A.

\section{Collection of $P$. butyracea fruits}

Fruits were collected in five muicipalities of nord Benin under permission from Department of the Environment of National Forestry Commission, approval N ${ }^{\circ}$ 2020-FOR-03-093PENESSOULOU. Sometimes, they are the foresters who bring us in the parks for the collection of the fruits.

\section{Experimental research and field studies on plants}

All experimental protocol and methods was approved by the Faculty of Agronomics Sciences (FSA) of Abomey-Calavi University (UAC), approval N²02040016. The fruits have been collected between May and June 2020 in five muicipalities of nord Benin, and transported to food laboratory of School of Nutrition and Food Sciences and Technologies of FSA for analyze. Moreover, an investigation was conducted between May and June 2020 in villages having a tradition of P. butyracea fruits processing. This survey was approved by the School of Nutrition and Food Sciences and Technologies (SNFST) of FSA, approval N ${ }^{\circ}$ F-025-2020-SNFST. Data were collected by administering questionnaires to randomly selected and willing respondents. To determine adequate number of respodents for survey, method according ${ }^{10}$ used.

\section{References}

1. Sinsin, B. \& Sinadouwirou, T. A. Valorisation socio-économique et pérennité du $P$. butyracea Sabine en galeries forestières au Bénin. Cah Agric 12,1-5 (2003).

2. Avocèvou-Ayisso, C. Etude de la viabilité des populations de Pentadesma butyracea Sabine et de leur socio-économie au Bénin. Thèse de doctorat, Université d'AbomeyCalavi, Benin (2011). 
3. Natta, A., Sogbégnon, R. \& Tchobo, F. Indigenous knowledge and importance of Pentadesma butyracea (Clusiaceae) for rural populations in north west Benin. Fruit Veg Cereal Sci Biotechnol 4, 18-25 (2010).

4. Ayegnon, B. P., Adjanohoun, G. \& Kayodé, A. P. P. Technological application of the butter of Pentadesma butyracea: A comparative evaluation of its cosmetic behaviour with Vitellaria paradoxa butter. Journal of Cereals and Oilseeds 10, 43-53 (2019).

5. Ayegnon, B. P., Kayodé, A. P. P., Tchobo, F. P., Azokpota, P., Soumanou, M. M. \& Hounhouigan, D. J. Profiling the quality characteristics of the butter of Pentadesma butyracea with reference to Shea butter. Journal of the Science of Food and Agriculture 95, 3137 - 3143 (2015).

6. Tchobo, P. F., Alitonou, G. A., Noudogbessi, J. P., Laguerre, M, B. B. \& Piombo, G. Evaluation of the chemical composition of Pentadesma butyracea butter and defatted kernels. Int Journal Biosci 3, 101-108 (2013).

7. Mbaiguinam, K., Mbayhoudel, K. \& Djekota, C. Physical and Chemical Characteristics of Fruits, Pulps, Kernels and Butter of Shea Butyrospermum parkii (Sapotaceae) from Mandoul, Southern Chad. Asian Journal of Biochemistry 2, 101-110 (2007).

8. Ugese, F.D., Baiyeri, P.K. \& Mbah, B.N. Nutritional composition of shea (Vitellaria paradoxa) fruit pulp across its major distribution zones in Nigeria. Fruits 63, 163-170 (2008).

9. Okullo, J. B. L., Omujal, F., Agea, J. G., Vuzi, P. C., Namutebi, A., Okello, J. B. A. \& Nyanz, S. A. "Proximate and Mineral Composition of She (Vitellaria paradoxa c.f. Gaertn) Fruit Pulp in Uganda." African Journal of Food, Agriculture, Nutrition and Development 10, 4430-4443 (2010).

10. Dagnelli, P. Statistiques théoriques et appliquées [Theoretical and applied statistics]. Brussels, Belgium: De Boeck (1998).

11. AOAC. Official methods of analysis, 16 th edn. Washington, DC: Association of Official Analytical Chemists (2002).

12. Nout, M.J. R., Rombouts, F. M. \& Havelaar, A. Effect of accelerated natural lacticfermentation of infant food ingredients on some pathogenic micro-organisms. Int. J.Food Microbiol 8, 351-361. (1989).

13. APHA. Compendium of Methods for the Microbiological Examination of Foods, 4th ed. American Public Health Association, Washington, D. C (2001). 
14. Kayodé, A. P. P., Linnermann, A. R., Nout M. J. R. \& Van Boekel M. A. J. S. Impact of sorghum processing on phytate, phenolic compounds and in vitro solubility of iron and zinc in thick porridges. J. Sci. Food Agric 87, 832-838 (2007).

15. Singleton, V. L. \& Rossi, J. A. Colorimetry of total phenolics with phosphomolybdicphosphotungstic acid reagents. Am. J. Enol. Vitic 16, 144-158 (1965).

16. Scherer, R., \& Godoy, H. T. "Antioxidant activity index (AAI) by the 2,2-diphenyl-1picrylhydrazyl method," Food Chemistry112, 654-658 (2009).

17. Assogbadjo, A. E., Sinsin, B. \& Van Damme, P. Morphological characters and production of baobab tree capsules (Adansonia digitata L.) in Benin. Fruits 60, 327340 (2005).

18. Kougblénou, N., Ahouansou, R. H., Aïssi, M. V., Houssou, P. A., Padonou, W. Fandohan, P., Mensah, G. A. \& Soumanou, M. M. Caractérisation physique du fruit et valeur nutritionnelle de la pulpe de karité (Vitellaria paradoxa) collecté dans différents parcs au Bénin, Bulletin de la Recherche Agronomique du Bénin (BRAB) 42 -48 (2012).

19. Akusu, O. M., Kiin-Kabari, D. B. \& Ebere, C. O. Quality Characteristics of Orange/Pineapple Fruit Juice Blends. American Journal of Food Science and Technology 4, 43-47 (2016).

20. Akubor, P. I. Evaluation of the Quality of Juice Prepared from African Bush Mango (Irvingia garbonensis Var. garbonesis) Fruit Pulp. Asian Research Journal of Agriculture 6, 1- 9 (2017).

21. Napio, R., Tumuhimbise, A.G. \& Agea, J.G. Nutritional composition and sensory evaluation of jam and juice processed from shea fruit pulp from Uganda. RUFORUM Working Document Series 14, 941-952 (2016).

22. Onimawo, I. A., Oteno, I., Orokpo, G. \& Akubor, P. I. Physicochemical and nutrient evaluation of African bush mango (Irvingia gabonensis) seeds and pulps. Plant Foods for Human Nutrition 3, 1-6 (2003).

23. Onimawo, I. A. \& Akubor, P.I. Food chemistry (integrated approach with biochemical background). 2nd Edn. Joytal Printing Press. Ibadan, Nigeria (2012).

24. Gyedu-Akoto, E., Amon-Armah, F. \& Yabani, D. Utilization of shea fruit to enhance food security and reduce poverty in Ghana. African Journal of Science, Technology, Innovation and Development 9, 697-705 (2017).

25. Aremu, M. O., Olonisakin, A., Bako, D. A. \& Madu, P. C. Compositional studies and physicochemical characteristics of cashew nut (Anarcadium occidentale) flour. Pakistan Journal of Nutrition 5, 328-333 (2006). 
26. Nnam, N. M. \& Njoku, I. E. Production and evaluation of nutrient and sensory properties of juices made from citrus fruits. Nigerian Journal of Nutritional Sciences 26, 62-66 (2009).

27. Omosuli, S. V., Ibrahim, T. A., Oloye, D., Agbaje, R. \& Jude-Ojei, B. Proximate and mineral composition of roasted and defatted Cashew Nut (Anarcadium occidentale) flour. Pakistan Journal of Nutrition 8, 1649-1651 (2009).

28. Adepoju, O.T. Geographic and yearly variation in nutrient content of shea butter (butyrospermum paradoxum Gaertn f.) fruit pulp. International Journal of AgriScience 3, 406-413 (2013).

29. Codex Alimentarius Commission, Programme mixte FAO/OMS sur les normes alimentaires. Rome: FAO (1999).

30. NBF 01-005, Normes Burkinabées pour le beurre de karité non raffiné . ABNOR (Agence Burkinabée de Normalisation), p 21 (2006)

31. Jantakee, K. \& Tragoolpua, Y. Activities of different types of Thai honey on pathogenic bacteria causing skin diseases, tyrosinase enzyme and generating free radicals. Biol Res 48, 1-11 (2015).

32. Siripatrawan, U., Vitchayakitti, W. \& Sanguandeekul, R. Antioxidant and antimicrobial properties of Thai propolis extracted using ethanol aqueous solution. Int Journal Food Sci Tech 48, 22-27 (2013).

33. Meng, J.F.; Fang, Y.L.; Qin, M.Y.; Zhuang, X.F. \& Zhang, Z.W. Varietal differences among the phenolic profiles and antioxidant properties of four cultivars of spine grape (Vitis davidii Foex) in Chongyi County (China). Food Chem 134, 2049-2056 (2012). 


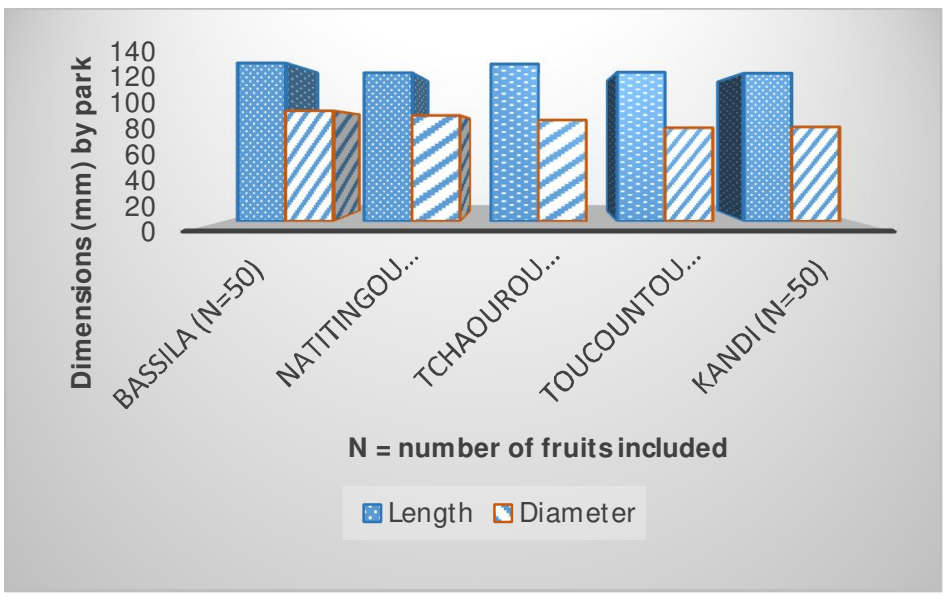

Figure 1 : Dimensions of $P$. butyracea fruits by park

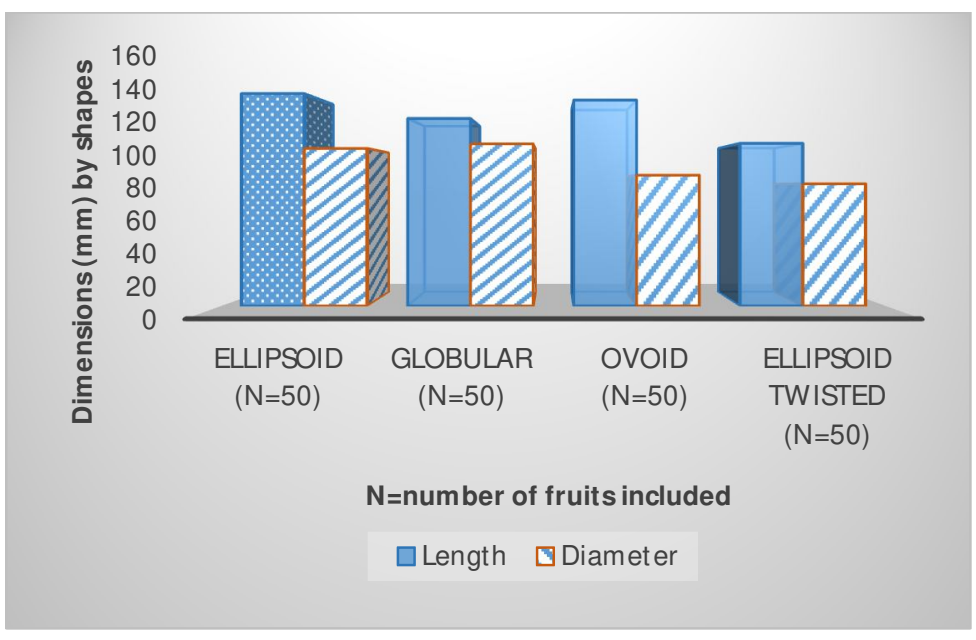

Figure 2 : Dimensions of $P$. butyracea fruits by shape 
Table 1 : Food, cosmetic and therapeutic uses of $P$. butyracea fruit pulp by different sociocultural groups (percent of producers surveyed, $\mathrm{N}=260$ )

\begin{tabular}{cccc}
\hline & \multicolumn{3}{c}{ Type of use } \\
\cline { 2 - 4 } Socio-cultural group & Food & Therapeutic & Cosmetic \\
\hline Boo $(n=35)$ & 8.45 & 97.30 & 0 \\
Nago $(n=52)$ & 2.63 & 45.20 & 0 \\
Anii $(n=40)$ & 4.25 & 100 & 7.5 \\
Otamari $(n=50)$ & 3.2 & 92 & 67.8 \\
Kotocoli $(n=30)$ & 2.15 & 96.80 & 89.5 \\
Waama $(n=37)$ & 2.10 & 94.30 & 77.6 \\
Fulani $(n=16)$ & 1.7 & 88.5 & 35.7 \\
Total $(\mathbf{N}=\mathbf{2 6 0})$ & $\mathbf{3 . 5 0}$ & $\mathbf{8 7 . 7 3}$ & $\mathbf{3 9 . 7 3}$ \\
\hline
\end{tabular}

Table 2 : Proportion of $P$. butyracea fruit pulp by park

\begin{tabular}{lccc}
\hline Parks & Fruit mass $(\mathbf{g})$ & Pulp mass $(\mathbf{g})$ & Proportion of pulp (\%) \\
\hline Bassila & $475.35 \pm 91.13 \mathrm{C}$ & $162.50 \pm 61.13 \mathrm{~d}$ & $39.12 \mathrm{C}$ \\
$(\mathrm{n}=50)$ & {$[242-705]$} & {$[94.34-304]$} & {$[23.54-42.53]$} \\
Natitingou & $389.11 \pm 71 \mathrm{~b}$ & $128.75 \pm 77.13 \mathrm{~b}$ & $35.71 \mathrm{~b}$ \\
$(\mathrm{n}=50)$ & {$[144-654]$} & {$[30-354]$} & {$[12.29-43.16]$} \\
Tchaourou & $461.25 \pm 74.04 \mathrm{C}$ & $143.15 \pm 76.62 \mathrm{C}$ & $37.71 \mathrm{~b}$ \\
$(\mathrm{n}=50)$ & {$[259-712]$} & {$[67-194]$} & {$[29.23-46.06]$} \\
Toucountouna & $347.51 \pm 56.31 \mathrm{a}$ & $97.75 \pm 58.82 \mathrm{a}$ & $33.67 \mathrm{a}$ \\
$(\mathrm{n}=50)$ & {$[123-497]$} & {$[45-121]$} & {$[25.89-40.14]$} \\
Kandi & $343.27 \pm 35.17 \mathrm{a}$ & $95.98 \pm 47.41 \mathrm{a}$ & $32.76 \mathrm{a}$ \\
$(\mathrm{n}=50)$ & {$[113-484]$} & {$[38-129]$} & {$[28.37-41.21]$} \\
\hline \multicolumn{1}{c}{ Average } & $\mathbf{4 0 3 . 3 0}$ & $\mathbf{1 2 5 . 6 3}$ & $\mathbf{3 5 . 7 9}$ \\
\multicolumn{1}{c}{ CV $^{2}$} & $\mathbf{1 5 . 4 2}$ & $\mathbf{2 2 . 9 7}$ & $\mathbf{7 . 4 5}$ \\
\hline
\end{tabular}

${ }^{1}$ Mean \pm Standard deviation; $\mathrm{n}=$ number of fruits included; values with the same letter in the same column, are not significantly different at $\mathrm{p}<0.05^{2} \mathrm{CV}=$ Coefficient of variation. 
Table 3 : Proportion of $P$. butyracea fruit pulp by shape

\begin{tabular}{cccc}
\hline Shapes & Fruit mass $(\mathrm{g})$ & Pulp masse $(\mathrm{g})$ & Proportion of pulp (\%) \\
\hline Elipsoid & $535.25 \pm 97.34 \mathrm{~d}$ & $204.50 \pm 61.77 \mathrm{~d}$ & $33.05 \mathrm{a}$ \\
$(\mathrm{n}=50)$ & {$[342-703]$} & {$[100-304]$} & {$[21.54-40.54]$} \\
Globular & $459.5 \pm 94 \mathrm{c}$ & $158.75 \pm 87.19 \mathrm{c}$ & $30.44 \mathrm{a}$ \\
$(\mathrm{n}=50)$ & {$[244-702]$} & {$[30-303]$} & {$[12.29-43.16]$} \\
Ovoid & $411.25 \pm 74.04 \mathrm{~b}$ & $137.25 \pm 96.66 \mathrm{~b}$ & $36.74 \mathrm{~b}$ \\
$(\mathrm{n}=50)$ & {$[259-541]$} & {$[67-199]$} & {$[29.23-46.06]$} \\
Elipsoid twisted & $241.50 \pm 60.36 \mathrm{a}$ & $81.75 \pm 31.82 \mathrm{a}$ & $33.30 \mathrm{a}$ \\
$(\mathrm{n}=50)$ & {$[161-297]$} & {$[45-121]$} & {$[25.99-40.74]$} \\
\hline Average & $\mathbf{4 1 1 . 8 7}$ & $\mathbf{1 4 5 . 5 6}$ & $\mathbf{3 3 . 3 8}$ \\
CV $^{2}$ & $\mathbf{3 0 . 2 3}$ & 35.00 & $\mathbf{7 . 7 4}$
\end{tabular}

${ }^{1}$ Mean \pm Standard deviation; $\mathrm{n}=$ number of fruits included; values with the same letter in the same column, are not significantly different at $\mathrm{p}<0.05 \cdot{ }^{2} \mathrm{CV}=$ Coefficient of variation.

Table 4. Chemical composition of $P$. butyracea fruit pulp by park

\begin{tabular}{llllll}
\hline Parameters & Bassila & Natitingou & Tchaourou & Toucountouna & Kandi \\
\hline Moisture (\%) & $85.88 \pm 1.23 \mathrm{a}$ & $86.47 \pm 2.05 \mathrm{a}$ & $85.77 \pm 3.12 \mathrm{a}$ & $85.94 \pm 2.13 \mathrm{a}$ & $86.44 \pm 1.27 \mathrm{a}$ \\
$\mathrm{pH}$ & $3.37 \pm 0.28 \mathrm{a}$ & $3.27 \pm 0.72 \mathrm{a}$ & $3.34 \pm 0.73 \mathrm{a}$ & $3.41 \pm 0.76 \mathrm{a}$ & $3.39 \pm 0.46 \mathrm{a}$ \\
Acidity titratable $(\%)$ & $0.73 \pm 0.34 \mathrm{a}$ & $0.82 \pm 0.12 \mathrm{~b}$ & $0.77 \pm 0.43 \mathrm{a}$ & $0.88 \pm 0.27 \mathrm{~b}$ & $1.03 \pm 0.55 \mathrm{c}$ \\
Crude fiber $(\%) \mathrm{dw}$ & $20.38 \pm 0.57 \mathrm{a}$ & $20.78 \pm 0.53 \mathrm{a}$ & $20.51 \pm 0.34 \mathrm{a}$ & $20.37 \pm 0.71 \mathrm{a}$ & $20.49 \pm 0.63 \mathrm{a}$ \\
Crude Proteins $(\%) \mathrm{dw}$ & $3.33 \pm 1.61 \mathrm{a}$ & $4.61 \pm 1.46 \mathrm{~b}$ & $3.65 \pm 2.11 \mathrm{a}$ & $4.45 \pm 1.23 \mathrm{~b}$ & $3.36 \pm 2.24 \mathrm{a}$ \\
Crude Lipids $(\%) \mathrm{dw}$ & $6.38 \pm 0.19 \mathrm{a}$ & $6.31 \pm 0.17 \mathrm{a}$ & $6.43 \pm 0.21 \mathrm{a}$ & $6.51 \pm 0.77 \mathrm{a}$ & $6.46 \pm 0.63 \mathrm{a}$ \\
Carbohydrate $(\%) \mathrm{dw}$ & $66.94 \pm 0.16 \mathrm{a}$ & $66.13 \pm 0.78 \mathrm{a}$ & $66.63 \pm 0.88 \mathrm{a}$ & $65.10 \pm 0.93 \mathrm{a}$ & $66.71 \pm 0.67 \mathrm{a}$ \\
Calorie $(\mathrm{Kcal}) \mathrm{dw}$ & $338.50 \pm 0.63 \mathrm{a}$ & $335.75 \pm 0.47 \mathrm{a}$ & $338.99 \pm 0.56 \mathrm{a}$ & $336.79 \pm 0.74 \mathrm{a}$ & $338.42 \pm 0.71 \mathrm{a}$ \\
Ash $(\%) \mathrm{dw}$ & $2.97 \pm 0.25 \mathrm{a}$ & $3.17 \pm 2.11 \mathrm{~b}$ & $2.78 \pm 1.57 \mathrm{a}$ & $3.57 \pm 0.77 \mathrm{~b}$ & $2.98 \pm 1.64 \mathrm{a}$ \\
$\mathrm{Fe}(\mu \mathrm{g} / \mathrm{g})$ & $176.44 \pm 0.76 \mathrm{c}$ & $198.03 \pm 0.34 \mathrm{a}$ & $194.57 \pm 0.77 \mathrm{~b}$ & $205.53 \pm 0.44 \mathrm{~d}$ & $193.37 \pm 0.41 \mathrm{~b}$ \\
$\mathrm{Ca}(\mu \mathrm{g} / \mathrm{g})$ & $1866.75 \pm 0.23 \mathrm{~b}$ & $1871.73 \pm 0.12 \mathrm{~b}$ & $1793.71 \pm 0.53 \mathrm{a}$ & $1921.75 \pm 0.77 \mathrm{c}$ & $1798.45 \pm 0.71 \mathrm{a}$ \\
$\mathrm{Zn}(\mu \mathrm{g} / \mathrm{g})$ & $16.82 \pm 0.33 \mathrm{a}$ & $18.84 \pm 0.23 \mathrm{~b}$ & $21.45 \pm 0.12 \mathrm{c}$ & $19.07 \pm 0.67 \mathrm{~b}$ & $20.87 \pm 0.57 \mathrm{c}$ \\
$\mathrm{Mn}(\mu \mathrm{g} / \mathrm{g})$ & $42.13 \pm 0.54 \mathrm{~b}$ & $49.51 \pm 0.83 \mathrm{a}$ & $40.71 \pm 0.71 \mathrm{~d}$ & $50.31 \pm 0.47 \mathrm{~d}$ & $46.77 \pm 0.36 \mathrm{c}$ \\
\hline
\end{tabular}

${ }^{1}$ Mean \pm Standard deviation; values with the same letter in the same line, are not significantly different at $\mathrm{p}<0.05$. 
Table 5. Microbiological qualiies of $P$. butyracea fruit pulp by park

\begin{tabular}{llllll}
\hline Microorganisms & \multicolumn{4}{c}{ Microbiological qualiies of pulp } \\
\cline { 2 - 5 }$\left(\log _{10} \mathrm{UFC} / \mathrm{g}-1\right)$ & Bassila & Tchaourou & Kandi & Natitingou & Toucountouna \\
\hline Aerobic mesophilic bacteria & $1.85 \pm 0.12 \mathrm{a}$ & $2.75 \pm 0.03 \mathrm{~b}$ & $2.20 \pm 0.09 \mathrm{~b}$ & $1.83 \pm 0.12 \mathrm{a}$ & $1.70 \pm 0.13 \mathrm{a}$ \\
Total coliforms & $1.11 \pm 0.21 \mathrm{a}$ & $2.14 \pm 0.05 \mathrm{~b}$ & $2.04 \pm 0.14 \mathrm{~b}$ & $2.37 \pm 0.03 \mathrm{~b}$ & $2.11 \pm 0.21 \mathrm{~b}$ \\
Faecal coliforms & $<1$ & $<1$ & $<1$ & $<1$ & $<1$ \\
Yeast and mould & $1.85 \pm 0.05 \mathrm{a}$ & $2.97 \pm 0.02 \mathrm{c}$ & $2.11 \pm 0.03 \mathrm{~b}$ & $1.87 \pm 0.21 \mathrm{a}$ & $2.17 \pm 0.05 \mathrm{~b}$ \\
Staphylococcus aureus & $1.05 \pm 0.22 \mathrm{a}$ & $1.37 \pm 0.34 \mathrm{a}$ & $1.13 \pm 0.01 \mathrm{a}$ & $1.20 \pm 0.03 \mathrm{a}$ & $1.12 \pm 0.09 \mathrm{a}$ \\
\hline${ }^{1}$ Mean \pm Standard deviation; values with the same letter in the same line, are not significantly different at $\mathrm{p}<0.05$.
\end{tabular}

${ }^{1}$ Mean \pm Standard deviation; values with the same letter in the same line, are not significantly different at $p<0.05$.

Table 6. Parameters of free radical scavenging activity by DPPH and Total phenolics of $P$. butyracea fruit pulp by park

\begin{tabular}{llll}
\hline Parks & $\mathrm{TPC}(\mathrm{mg} / \mathrm{ml} \mathrm{dw})$ & $\mathrm{EC}_{50}(\mathrm{mg} / \mathrm{ml} \mathrm{DPPH})$ & $\%(\mathrm{DPPH})$ remaining \\
\hline Bassila & $23.22 \pm 0.03 \mathrm{~b}$ & $0.012 \pm 0.07 \mathrm{a}$ & $15.07 \pm 0.14 \mathrm{c}$ \\
Tchaourou & $22.86 \pm 0.01 \mathrm{~b}$ & $0.014 \pm 0.21 \mathrm{~b}$ & $13.15 \pm 0.09 \mathrm{~b}$ \\
Kandi & $25.98 \pm 0.11 \mathrm{c}$ & $0.010 \pm 0.23 \mathrm{~d}$ & $10.83 \pm 0.07 \mathrm{a}$ \\
Natitingou & $23.52 \pm 0.05 \mathrm{~b}$ & $0.011 \pm 0.03 \mathrm{c}$ & $12.74 \pm 0.01 \mathrm{~b}$ \\
Toucountouna & $21.54 \pm 0.03 \mathrm{a}$ & $0.017 \pm 0.11 \mathrm{a}$ & $22.54 \pm 1.17 \mathrm{~d}$ \\
Ascorbic acid & - & $0.0018 \pm 0.0014$ & $7.48 \pm 0.01$ \\
Gallic acid & - & $0.0020 \pm 0.0001$ & $9.83 \pm 0.03$ \\
\hline
\end{tabular}

${ }^{1}$ Mean \pm Standard deviation; values with the same letter in the same column, are not significantly different at $\mathrm{p}<0.05$. 


\section{Figures}

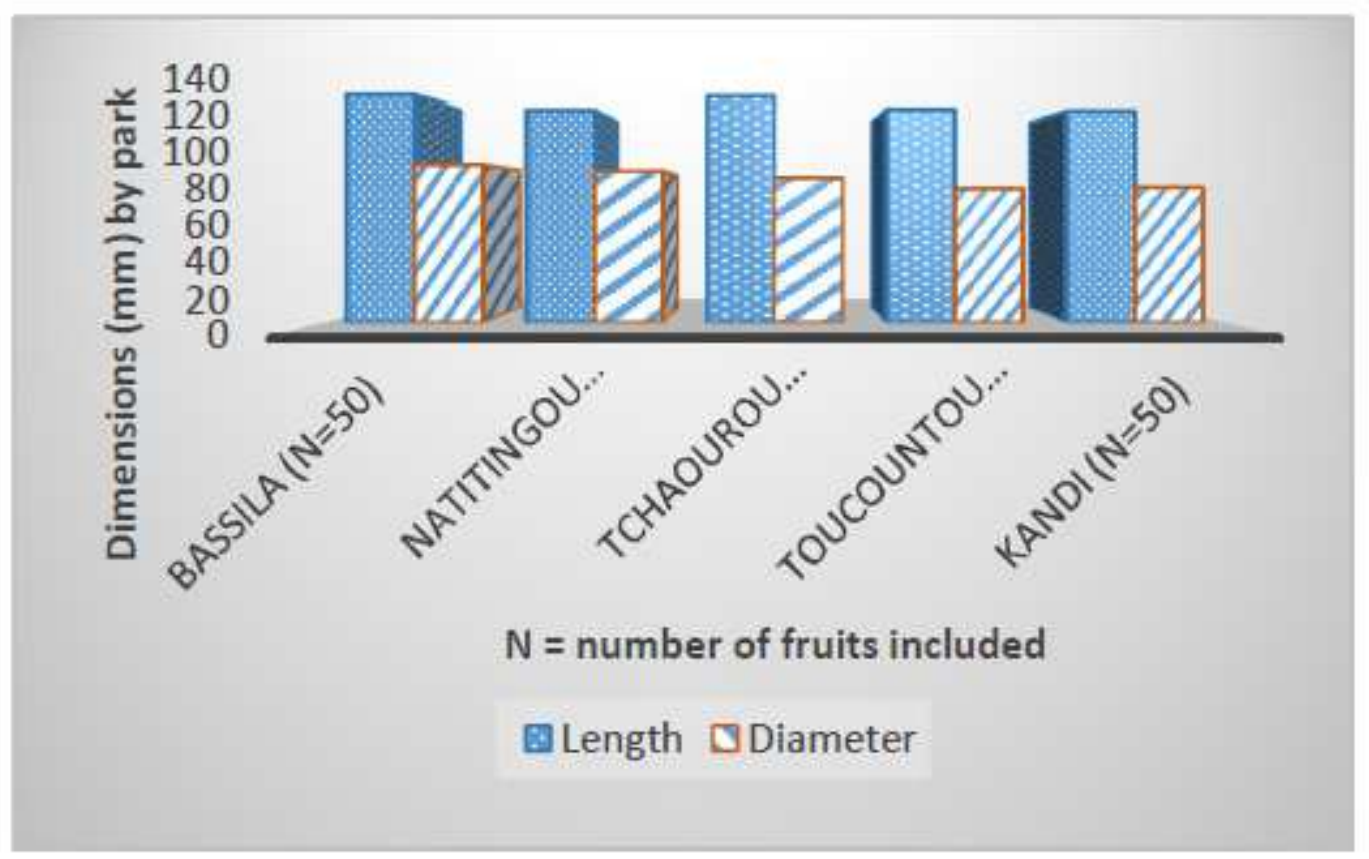

Figure 1

Dimensions of P. butyracea fruits by park

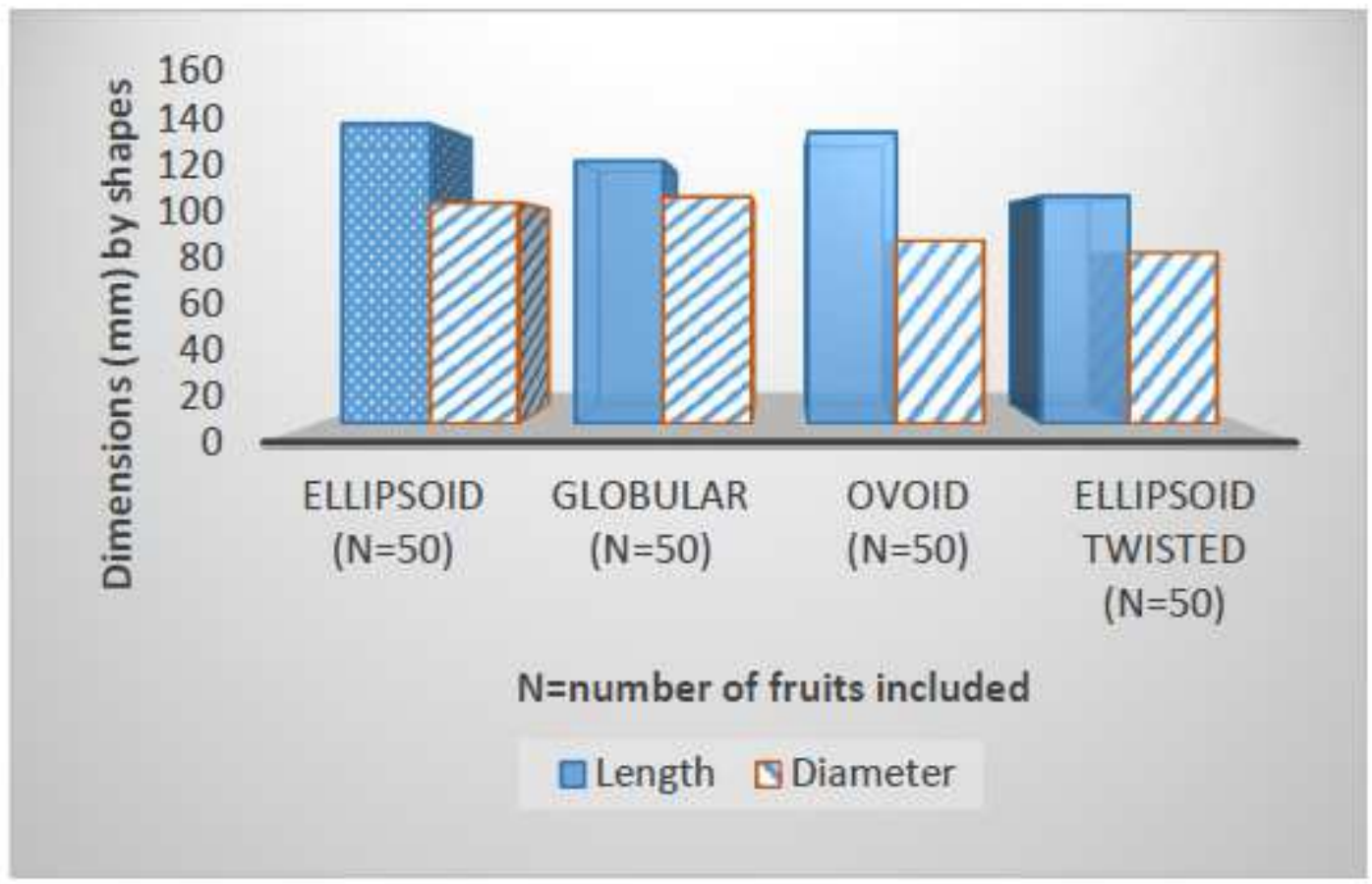

Figure 2

Dimensions of P. butyracea fruits by shape 


\section{Supplementary Files}

This is a list of supplementary files associated with this preprint. Click to download.

- GraphicalAbstract.pdf 